\title{
Descriptive Study: Cross-Nation Marriage Family between Foreign Citizen and Local Citizen in Timbang Jaya Village, Bahorok Sub-District, Langkat Regency
}

\author{
Sihar Pandapotan ${ }^{1}$ \\ Universtas Terbuka Medan, Indonesia
}

\begin{abstract}
This study is about cross-nation marriage aiming to understand the factors of cross-nation marriage happened, understand the difficulties in parenting pattern introduced in cross-nation marriage, understand how the implication of daily life's pattern applied, and understand the difficulties faced by the parents who come from different cultural backgrounds in running household. Meanwhile the result of this study is that there were many differences in pattern of life which is applied in their families, starting from the language used in daily, food consumed, and the way of thinking in their families. Although the status of citizenship of the foreign citizens were the same from the several families studied, in running their lifes, there were some differences based on their personalities and neighborhoods, some were ease to assimilated with the society around, some were hard to adapt with the society and the cultures of Indonesia, in general. Moreover, the general difference between west culture and east culture is the west culture tends to own more freedom and the east culture tends to limit the freedom of a child in having a decision. According to these phenomena, the author could see how their interactions with the society in the neighborhood were, how their status were, how their behavior in practicing the custom and culture and pattern of daily life was. In this study, the author used the qualitative method as a reference to get the data significantly from the main informants. Furthermore, the author used the technique of collecting data by interviewing to get the more comprehensive data.
\end{abstract}

Keywords

cross-nation marriage; foreign citizen; local citizen.

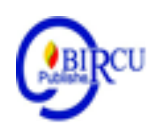

\section{Introduction}

Bahorok is subdistrict of Langkat regency, Sumatera Utara, Indonesia where its capital is Bahorok Town. Most of the area of this subdistrict locates in Gunung Leuser National Park included Bukit Lawang. Bukit Lawang is the most well-known attraction among others because people can see the Orangutans there and many tourists come to see them up directly. Nowadays the visits of international tourists are improving, it is noted that there were 5.185 tourists in 2008 then rose up to 8.544 in 2009 , and there were 8.931 of international tourists in 2010 visiting Bukit Lawang. In the next year, based on the data gotten from the section office of region V Gunung Leuser National Park (TNGL) Bukit Lawang in 2013, the domestic tourists who visited the Bukit Lawang were 3.152 and the International tourists were 7.182. In 2014 although the visits of domestic tourists were increased up to 3.868 people, the visits of international tourists were decreased for only 6.415 people. Meanwhile in 2015, the number of domestic tourists visiting also had a decrease in 3.762 and international tourists 
declined to 3.485. In 2016 the visits of both the international and the domestic tourists increased up to about 10.201 people.

The data above showed that the existence of Bukit Lawang becomes one of the attraction destinations for international tourists, particularly for the tourists from Europe and other countries like England, France, Switzerland, Holland, Germany, and so on. In each year, there will be some foreign tourists staying in Bukit Lawang for couples days or weeks. In this present time, the coming of the foreign tourists to stay or even to have marriage with the local residents (WNI) has been so much going on and become an ordinary phenomenon. Beginning from having holidays, doing business, there comes love among the guides and the tourists. In the meantime, according to the one of the main informants called Gitok, who is one of the senior tour guides since 1980 said that the society of the village in the beginning a little bit felt unfamiliar with the cross-nation marriage, but by the time flies it gradually became usual among the society. It is not a taboo thing anymore to have a cross-nation marriage. It is proved from the data of the author in $2014-2016$ that there are 5 marriages which are registered and take place at The Office of Religious Affairs (KUA) of Bahorok, meanwhile the data from The Office of civil registries (Capil) of langkat Regency from 2014 until 2016 there are six couples who are registered to have cross-nation marriage among foreign citizens and local citizens. The data gotten from The Office of Religious Affairs and from The Office of civil registries are not suitable with the data from a main informant; it may be caused by many reasons. Many of the local citizens who have marriage in other provinces or even other countries, decide to live in the home land of the foreign citizens (their couples) by the reason of the life established and the occupation they had before. Until now, there are 20 couples of cross-nation marriage who live in Timbang Jaya Village. According to the source from the head of the village, the couples of the cross-nation marriage spread in several hamlets, there is a cross-nation marriage family in hamlet I, 4 families in hamlet III, 12 families in hamlet IV and the last 2 families in hamlet V. It is only hamlet I which doesn't have the cross-nation marriage family. Moreover, most of them live in the big cities and famous tourists destinations such Jakarta, Bandung, and Bali. Yet, after marriage, there are many local citizens who are brought up to live abroad in the home lands of their couples.

However, the cross-nation marriage brings up some problems, like the implication of two patterns of life, and the significant difference of the culture which absolutely involves the acculturation culture but it doesn't hit all the member of the family, and the effect to the family and the society causing by the cross-nation marriage. Meanwhile the couples of the cross-nation marriage in Timbang jaya village are both the native people and the entrants who now live in Timbang Jaya village.

\section{Theoretical Framework}

With the growing tourism industry which develops in Bukit Lawang, that place becomes one of the tourist attractions that is visited by the international tourists. This can be seen that the more year it is, the more people sign up to Indonesia Tourism Repository (HPI) to become tour guides in hotels or homestays and the more new hotels or homestays are opened in every year, but the facilities of the hotels are not as good and as fascinating as theirs in Medan or other big cities. At the end, this becomes a good prospect to the foreign investors to have a corporation with the local citizens.

This opportunity became a beginning to the tour guides (local citizens) to get know their tourists, their partners at non-governmental organizations (LSM) or their partners at travel business who are mostly foreign citizens. They finally decided to get married after 
having many considerations although they have many differences in the way of thinking, cultures, races, religious, and many more. Therefore, the acculturation or even the assimilation cannot be separated and avoided in their lifes. The dominant culture or indigenous culture commonly influences the culture of the minority or the immigrant culture, and subsequently, the minority culture is affected by the dominant culture due to the cultural pressures of the culture itself (Saragih, 2019). Culture cannot be separated from religious life, which is a manifestation of ethnic theology and cosmology (Zulkifli and Ridwan, 2019).

Marriage is the process by which two people make their relationship public, official, and permanent. It is the joining of two people in a bond that putatively lasts until death, but in practice is increasingly cut short by divorce. Over the course of a relationship that can last as many as seven or eight decades, a lot happens. Personalities change, bodies age, and romantic love waxes and wanes. And no marriage is free of conflict. What enables a couple to endure is how they handle that conflict. (Jamaluddin, 2018)

This cross-nation marriage has much different background, starting from the language, the way of thinking, and also the pattern of life. The result of this study showed that the acculturation cannot be separated in the cross-nation marriage. In fact, the reality that the author caught in their real families, the cross-nation marriage families doesn't face the assimilation, but the acculturation and the enculturation do.

\section{Research Method}

In this research, the author used the qualitative approach so that it produced descriptive data in the form of words, written, or spoken from the behavior of a person analyzed (researched). According to the Richie in Moleong (2006:5) explains that qualitative method is an effort to serve the social world and its perspective in a world, from the concept of point of view, behaviorism, perception, and matters of human researched.

\subsection{Subject of the Research}

The informants used in this research were the people who have cross-nation marriage with the foreign citizen or "Bule" that have been researched. Then, the author used the Nonprobability Sampling, it is a choosing sample technique which gives the same opportunity for every participant or chosen to be a sample. In this case, the author decided the subject that had been researched as an informant (purposive sampling). As an early step, the main subject was the person who does the cross-nation marriage between the local citizen and the foreign citizen who have children, religious figures, and the society around the residence of the research place.

Criteria:

1. Having cross-nation marriage between the local citizen and the foreign citizen.

2. Having been married for 5 years.

3. Having child/children.

4. Live in Timbang jaya Village.

According to the criteria above, the researcher had 5 couples of cross-nation marriage as main informants who live in Timbang Jaya Village, they are:

1. The couple of Zainan (Indonesia) and Brigitte (France).

2. The couple of Patris Bouchet (France) and Fitri (Indonesia).

3. The couple of Kris (France) and Rose (Indonesia).

4. The couple of Matthew Lee Pepper (London) and Leni (Indonesia).

5. The couple of Nicholas (London) and Atik (Indonesia) 


\section{Discussion}

\subsection{The Factors that Cause the Cross-Nation Marriage}

The Thing that becomes the main factor to have the cross-nation marriage is the change current of globalization which affects to the all lines, and one of them is cross-nation marriage phenomenon. The develops of the tourism sector and technology can lead the foreigners to come to Indonesia and to adapt.; as well as the tourism sector that grows fast offers many attractions to the international tourists. By the arriving of the international tourists to Indonesia, it makes the acculturation cannot be avoided in Indonesia. For example the cross-nation marriage happened in Timbang Jaya Village. It is true that the root of the cross-nation marriage in the village is because of the acculturation, but when the author researched more there were some factors of the local citizens to marry the foreign citizens, some of them were: love involving among the guides and the tourists, the partners in nongovernmental organization (LSM), and the partners at travel business, another factor was the financial factor (prosperity and prestige). The poverty that suffers several residents in Timbang Jaya Village had the people decide to have cross-nation marriage with a foreign citizen because they thought it could change their life and made their finance better. A nonkey informant who has the cross-nation marriage admitted to marry a foreign citizen because of financial reason. It is Bobi, a man born in Binjai, 30. At that time, the author came in the morning to the house well as the homestay. When he was interviewed, he bluntly said that one of his reasons to decide marrying foreign citizen was for a guarantee of a more settled life.

Not only that, another factor that causes the cross-nation marriage is that the failure of the people to have marriage with the local citizens. It causes the local citizens decided to turn away and marry the foreign citizens. One of the informants was Rose having the reason to have cross-nation marriage because of the trauma for having relationship with Indonesian Man. It was only counting down the days to get married with the guy, but everything ruined and brought up a heavy trauma to her about Indonesian guy although it hadn't yet gotten the marriage.

Another factor for a local citizen to marry a foreign citizen is to change significantly the physical appearance of their descendants. In general, the informants and the society think when a local marries a foreigner, specially the European; the children of the couple will have a pointed nose, tall body, and white skin. Some of the informants said having a child from cross-nation marriage can be said as luck for the couple of the cross-nation marriage in Timbang Jaya Village. The descendant from a cross-nation marriage with the foreign citizen will have a better physical appearance.

\subsection{Parenting Pattern Applied}

In general the description to educate children in cross-nation marriage is following the mother's pattern and affected by the neighborhood. It happens because the mother takes a dominant part as well as the neighborhood to affect the behavior, the attitude, the way of thinking, and the character of a child. From 5 main informants, 3 of them apply the parenting pattern which is more dominant to the mothers, where the fathers are local citizens. They said the parenting pattern which is applied should fit with the culture and the values of the social police around. However, there are 2 couples of the cross-nation marriage apply the parenting pattern more dominantly to the father's pattern who are the foreign citizens. However, when the couples get divorced or the foreign citizen of the couple passes away, the parenting pattern that is applied before little by little has started to fade away because the children will 
be raised and educated by the different parenting pattern from the local citizen of the couple. Yet, in fact, all the cross-nation marriage family apply the west and east culture in accordance with their needs in the perspective of family of something. However, there is one thing that is really dominant applied to all members of the cross-nation marriage family, namely the freedom given by the parents to the children. The freedom cannot be separated from the values and the laws that are embraced by the society and as long as the action of a child is still considered to be good, he will be given freedom.

\subsection{The Effect of Pattern of Life}

Discussing about the pattern of life applied in a cross-nation marriage, there must be acculturation and enculturation in their life. The theory of acculturation is the fundament of this research which takes a main role and becomes the basis of this writing, each thing relates to the concept about social process involving. If a group of people make interaction with another culture in a long term, it will gradually affect their own culture without removing their original culture, it is called by acculturation. The author saw there were some things that seemed to be experiencing the acculturation of culture from the pattern of life of the crossnation marriage, like food. The food that they consume daily, in general is a combination between western and eastern food. Next the use of daily language, they are bilingual, they use both Bahasa and English. Not only that, the culture of the foreign citizens has been adapted with the local culture, like the occupation that they run, namely farming and goldfish cultivating, and also hostelry for local and international tourists.

\subsection{The Difficulties Mostly Faced by the Cross-Nation Marriage}

In establishing the harmony in a family, a good communication among the family members will have it easy to achieve. One of the types of a good communication is the way of a person using the language. Though, the different language is used in a cross-nation marriage family. It can be a big matter among the family members to have miscommunication or misperception, although it happens many times. The different way of thinking, especially the different parenting pattern, sometimes makes the parents understand each other and yield in caring the children. For example the foreign parent wants the children to get school in their home land or have an international standard school in Indonesia. In the term of food, generally the local parent consumes the hot and spicy food, but when they get married with the foreign citizen they need to make their own food or even sometimes they don't use any chilly or pepper in the seasoning so that it can be consumed together. Furthermore, according to Atik, one of the author's informants said that the foreigners "Bule" are mostly tend to be more stubborn than the local citizen, both men and women, so to negotiate a deal, the local citizens should have a better understanding of their couples.

\section{Conclusion}

Based on the research conducted in the Timbang Jaya Village, so the author took same conclusions gotten from the data, they are:

There are some factors to have a cross-nation marriage in Timbang Jaya Village and the financial factor comes the first because many people in Timbang Jaya Village live under the standard of welfare, so that the result from my 2 informants said briefly that having crossnation marriage with the "Bule" was their choice to change their life and their big family's life both for the man and the woman. The financial factor was not the only main role. Starting 
as a partner in non-governmental organization (LSM), in a tour travel or even with the tourist can bring up the love in the air and finally decide to have cross-nation marriage, and the last factor was because of the trauma to have relationship with the local citizen, like what happened to one of the informants with an Indonesian guy. That trauma took her to marry a "Bule".

Parenting pattern which is applied in all of the family of cross-nation marriage has applied the western and eastern pattern, but there are 3 couples who are more dominantly apply the eastern culture and there are 2 other couples who are more dominantly apply the western culture. It is one of the challenges for the people who want to have cross-nation marriage. The positive thing that we can take is giving freedom to the children but still in the limitation of values and norms of social policies in Indonesia. As long as it is positive and acceptable, the family of cross-nation marriage will take it and adapt it in their families.

There must be the implication or the effect of pattern of life of a cross-nation couple between the local and the foreign citizen, although it doesn't hit the whole part. The result of this research, all families must have faced the acculturation of culture, whether it came from the foreign or from the local citizen. For example from the way of thinking, dressing, or even the language using, there seemed to be a change in the implementation in their families. They not only face the acculturation, but also in the reality the family of cross-nation marriage face the enculturation of culture or giving culture to their children and families. Yet, in this research it was not elaborated too deep, which means the family not only face the acculturation but also the enculturation. The results of this research had several similarities from the citizenship researched, and also had differences in the way of thinking and the principles in different life. It means it cannot be said that ever western people "Bule" has the same way of thinking or principle of life whether they come from the same country. All that is back to each individual, how he runs life and able to adapt with the surrounding, because the process of the introducing and giving the culture to the children is conducted by the parents to the children. For example the parents communicate with foreign language, and also the learning of values and norms in accordance with the social laws of Indonesia given to every member of the family.

The difficulty that clearly seems in having a cross-nation marriage is language. Language becomes the main obstacle for every family. Not knowing in language can take to a misunderstanding that happens a lot although they can understand the daily spoken of the language. According to Kak Atik, one of the informants, said that the foreigners "Bule" are mostly tend to be more stubborn than the local citizen, both men and women, so to unite the different opinions, the local citizens should have a better understanding of their couples. Moreover, the different way of thinking, especially the parenting pattern, sometimes makes the parents must understand each other in caring the children.

\section{References}

Abdullah, Irwan. (2006). Konstruksi Dan Reproduksi Kebudayaan. Yogyakarta. Pustaka Pelajar.

Bergner, Elizabeth Hurlock. (1990). Perkembangan Anak. Jakarta . Erlangga.

Depdikbud.(1988). Kamus Besar Bahasa Indonesia.Jakarta . Balai Pustaka

Hadikusumah, Hilman. (2007). Hukum Perkawinan Indonesia. Bandung. Mandar Maju. . (2010). Pengantar Antropologi Hukum. Bandung. Citra Aditya Bakti.

Horton, Paul B. dan Hunt Chester L. 1999. Sosiologi Edisi Keenam. Terjemahan Aminuddin Ram dan Tita Sobari. Jakarta.Erlangga. 
Kaplan, David. (1999). Teori Budaya. Pustaka Pelajar. Yogyakarta

Koentjaraningrat. (2002). Pengantar Ilmu Antropologi. Jakarta: Rineka Cipta . (1980). Sejarah Antropologi I. Jakarta: UI Press

(1983). Metode-Metode Penelitian Masyarakat. Jakarta: PT. Gramedia . (1990). Sejarah Teori Antropologi II. Jakarta: UI Press.

Damanik, Erond Litno. (2015). Karya Tulis Ilmiah. Medan. Simetri Publisher

Gordon, Myron Milton. (1968). Assimilation in American Life: The Role of Race, Religion, and National Origins. New York. Free Press.

Jamaluddin. (2018). AL Ghazali's View Regarding to the Witness in Islamic Wedding Ceremony Budapest International Research and Critics Institute-Journal. P. 01-10.

Moleong, Lexy J. (2006). Metodologi Penelitian Kualitatif. Bandung.P.T Remaja Rosda.

Papafragos, H. (2008). Perkawinan Antar Bangsa. Love and Shock!. Jakarta. Penerbit Erlangga.

Prawirohamidjojo, R. Soetojo Dan Asis Safioedin. (1986). Hukum Orang Dan Keluarga. Bandung.Alumni.

Renalds, T. G. (2011). Communication in Intercultural Marriages: Managing Cultural Differences and Conflict for Marital Satisfaction. Unpublished Master.Thesis. Lynchburg.Department of Communication Liberty University.

Robert Bogdan dan Steven Taylor, (1993).Kualitatif: Dasar-dasar Penelitian. Usaha Nasional.Surabaya.

Scott, James. (1976).The Moral Economy of Peasant.Yale University Press. New Haven.

Saragih, Hisarma et al. 2019. The struggle of Batak Simalungun for their identity in Church organization in Simalungun, Medan, Indonesia. Journal of Human Behavior in the Social Environment, 693-704.

Soekanto, Soerjono. (2009). Sosiologi Keluarga: Tentang Ikhwal Keluarga, Remaja Dan Anak. Jakarta. Rineka Cipta

Sugiyono. (2010). Metode Penelitian Kuantitatif, K.ualitatif Dan R\&D. Bandung. CV. Alfabeta.

Sasmiar. (2011). Perkawinan Campuran Dan Akibat Hukumya. Jurnal Ilmu Hukum. Volume 02, Nomor 02.

Zulkifli and Ridwan, Muhammad. 2019. Revitalization of the Traditional Values Lost Due to the Commodification of Art/Crafts: A Case Study of Bataknese traditional Ulos. Asian Ethnicity, 541-554. 